\title{
Chemical and functional properties of roasted spitting cobra ( $N$. nigricollis)
}

\author{
H. N. Ogungbenle,* and P. T. Adaraniwon
}

Department of Chemistry, Ekiti State University, P.M.B. 5363, Ado-Ekiti, Nigeria

\begin{abstract}
The proximate, nutritionally valuable minerals, amino acids and functional properties of roasted spitting cobra (Naja nigricollis) were studied. The results show that the sample contains $6.36 \%$ moisture, $79.45 \%$ crude protein, $6.35 \%$ fat and $2.96 \%$ carbohydrate. The highest mineral was phosphorus with $160.96 \mathrm{mg}$ per $100 \mathrm{~g}$ and the sample was low in copper, chromium and cobalt. The protein solubility was minimum at $\mathrm{pH} 4.0$ and maximum at $\mathrm{pH} 8.0$. The total amino acid in the sample was $76.84 \mathrm{~g} / 100 \mathrm{~g}$ protein while the total essential amino acid in the sample was $35.53 \mathrm{~g} / 100 \mathrm{~g}$ protein. The sample also exhibits $9.28 \%$ water absorption capacity, $118.83 \%$ oil absorption capacity, $11 \%$ foaming capacity, $2 \%$ foaming stability, $30 \%$ emulsion capacity, $70 \%$ emulsion stability, $30 \%$ of least gelation concentration.
\end{abstract}

Keywords: Chemical; Functional; Amino acid; Roasted; Cobra

\section{Introduction}

Spitting cobra (Naja nigricollis) is one of the edible species of snake found in terrestrial habitat. It is a type of animal which belong to the class called reptilia, phylum chordata, sub-phylum vertebrata and has the ability to eject venom from their fangs when defending themselves against predators. The sprayed venom has no harmful effect on skin. However, it can cause permanent blindness if introduce to the eye and left untreated causing chemosis and corneal swelling. The vast majority of snakes are not dangerous to man but about three hundred species are venomous. Between 30,000 to 40,000 people died from snake bite every year and most of these deaths are prevalent in southwest Asia but less than 100 people die each year from snake bite in United States (Miller and Harley, 2005). The aim of this work is to determine the chemical composition, minerals, amino acids and functional properties of roasted spitting cobra (Naja nigricollis).

\section{Materials and methods}

The fresh Spitting cobra (Naja nigricollis) was obtained at the Ekiti State University, Ado-Ekiti campus. The intestines and other internal organs were removed. It was later roasted on fire during which the scales covering the skin were removed. The sample was further air-dried and grinded into powder using a blender. The proximate analysis was carried out using the method described in AOAC(2005) and nitrogen content was converted to protein by multiplying by 6.25 . Carbohydrate was determined by method of difference. All determinations were done in triplicate. The method of Sathe et al. (1982) was used to determine gelation property with slight modification.The water and oil absorption capacities of the sample were determined as described by Beuchat (1977).The emulsion capacity and stability were determined by the method of Yasumatsu et al. (1972) while foaming capacity and stability were determined by method of Coffmann and Garcia (1977). The protein solubility as a function of $\mathrm{pH}$ was determined by method described by AOAC (2005). The minerals ( Sodium and potassium) were determined by using a flame photometer (model 405, corning, U.K) while others were determined by Atomic Absorption Spectrophotometer (Perkin \& Elmer model 403, USA). The amino acid profile was determined using the method described by Spackman et al. (1958).

\section{Results and discussion}

The proximate composition of spitting cobra (Naja nigricollis) is shown in Table I. The crude protein content $(79.16 \%)$ of spitting cobra (Naja nigricollis) is higher than those 
reported for python (49.99\%), Cuban boa (63.50\%), cattle egret $(76.72 \%)$ and grass cutter (22.70\%) (Abulude, 2007). Therefore, the sample is very rich in protein. The fat content $(6.35 \%)$ of the sample is low, indicates that cobra meat when

Table I. Food properties of spitting cobra (Naja nigricollis)

\begin{tabular}{lc}
\hline Component & $\%$ \\
\hline Crude protein & 79.16 \\
Ash & 5.17 \\
Moisture & 6.36 \\
Fat & 6.35 \\
Fibre & $\mathrm{ND}$ \\
Carbohydrate & 2.96 \\
Water absorption capacity & 9.28 \\
Oil absorption capacity & 118.83 \\
Foaming capacity & 11.00 \\
Foaming capacity at 60 minutes & 2.00 \\
Emulsion capacity & 30.00 \\
Emulsion stability & 70.00 \\
Least gelation concentration(W/V) & 8.00 \\
\hline
\end{tabular}

$\mathrm{ND}=$ not detected

consumed can serve good antidote for those that have fat related disease such as arteriosclerosis. The water absorption capacity is $9.28 \%$ while oil absorption capacity $(118.83 \%)$ is higher than that of variegated grasshopper (33.3\%) (Olaofe et al., 1998). The foaming capacity and stability of spitting cobra were low. The emulsion stability of the sample (70\%) is high as shown in Table I, this implies that the sample may be good for food formulation. The sample has minimum protein solubility at $\mathrm{pH} 4.0$ (Fig 1).Table II shows the mineral

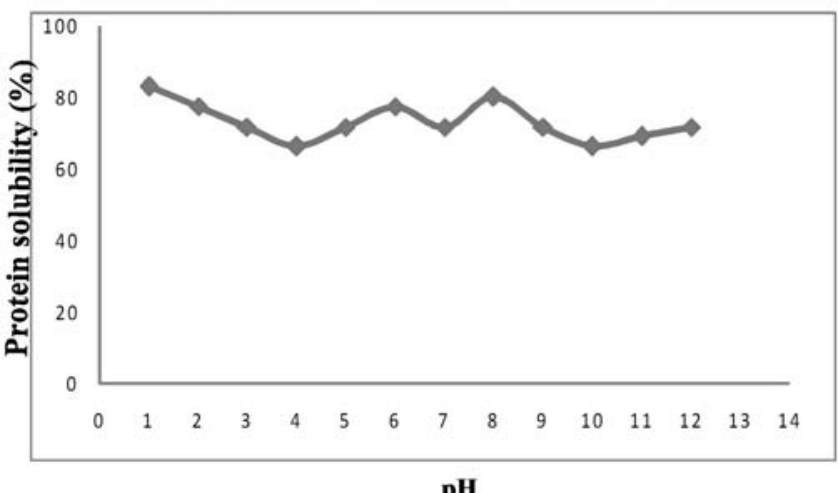

Fig. 1. Effect of pH on protein solubility curve of spitting cobra (Naja nigricollis) compositions. The values of iron and zinc were higher than that reported by Adeyeye et al (1996) for fresh water fish $(0.2-0.5 \mathrm{mg} / 100 \mathrm{~g})$. The values obtained for zinc and iron at were significantly higher than $0.88 \mathrm{mg} / 100 \mathrm{~g}$ and $0.49 \mathrm{mg} / 100 \mathrm{~g}$ respectively reported by Guner et al (1997) for fishes in Turkey. The high content of calcium in Naja nigricollis indicates that its consumption can increase the calcium in the body. The magnesium content $(60.87 \mathrm{mg} / 100 \mathrm{~g})$ of spitting cobra is higher than the values for four breeds of land snail in Nigeria reported by Babalola and Akinsoyinu (2009). The values of sodium and potassium obtained were higher than the range $(12.5-63.1 \mathrm{mg} / 100 \mathrm{~g})$ and $(12.5$ $16.9 \mathrm{mg} / 100 \mathrm{~g}$ ) respectively reported for Nigerian fresh water fish (Adeyeye et al; 1996). The copper content $(0.08 \mathrm{mg} / 100 \mathrm{~g})$ of the cobra is in the range of that reported by Odukoya and Ajayi (1987) for fresh water fish (0.03$0.35 \mathrm{mg} / 100 \mathrm{~g})$. Phosphorus $(160.96 \mathrm{mg} / 100 \mathrm{~g})$ is the highest mineral in the sample while chromium is the lowest. Spitting cobra (Naja nigricollis) is found to be rich in essential nutrients required for a healthy living.

Table II. Mineral composition of spitting cobra (Naja nigricollis)

\begin{tabular}{lc}
\hline Minerals & $\mathrm{mg} / 100 \mathrm{~g}$ \\
\hline Sodium $(\mathrm{Na})$ & 63.49 \\
Potassium (K) & 71.59 \\
Calcium (Ca) & 66.81 \\
Magnesium (Mg) & 60.87 \\
Zinc (Zn) & 50.52 \\
Iron (Fe) & 32.85 \\
Phosphorus (P) & 160.96 \\
Manganese (Mn) & 17.18 \\
Copper (Cu) & 0.08 \\
Chromium (Cr) & 0.04 \\
Cobalt $(\mathrm{Co})$ & 0.12
\end{tabular}

The amino acid compositions of spittng cobra (Naja nigricollis) is shown in Table III. The result indicates that the total essential amino acid (with histidine) is $35.53 \mathrm{~g} / 100 \mathrm{~g}$ crude protein .This value is lower than $35.73 \mathrm{~g} / 100 \mathrm{~g}$ crude protein obtained for periwinkle meat (Ogungbenle and Omowole, 2012 ) and $52.23 \mathrm{~g} / 100 \mathrm{~g}$ crude protein for rabbit meat (Simonova et al, 2010) but higher that of Ostrich meat (without phenylalanine) (Sales and Hayes, 1996). Glutamic acid is 
the highest amino acid $(12.27 \mathrm{~g} / 100 \mathrm{~g}$ crude protein) in the sample followed by aspartic acid $(8.90 \mathrm{~g} / 100 \mathrm{~g}$ protein). The results indicate that Naja nigricollis contains balanced essential amino acid and highly suitable for the fortification of maize food products which are widely used as weaning for children in most African countries (Akerele and Edward, 1971).

Table III. Amino acid composition of spitting cobra (Naja nigricollis)

\begin{tabular}{lr}
\hline Amino acids & g/ $100 \mathrm{~g}$ crude protein \\
\hline Lysine & 5.81 \\
Histidine & 2.21 \\
Arginine & 5.09 \\
Threoline & 3.15 \\
Valine & 4.33 \\
Methionine & 2.03 \\
Isoleucine & 3.20 \\
Leucine & 6.04 \\
Phenylalanine & 3.67 \\
Aspartic acid & 8.90 \\
Serine & 3.36 \\
Glutamic acid & 12.27 \\
Proline & 3.46 \\
Glycine & 4.61 \\
Alanine & 4.90 \\
Cysteine & 0.79 \\
Tyrosine & 3.02 \\
Total amino acid (TAA) & 76.84 \\
Total essential amino acids (TEAA) with Histidine & 35.53 \\
Total essential amino acids (TEAA) without Histidine & 33.32 \\
Total non-essential amino acids (TNEAA) & 41.31 \\
Total acidic amino acids (TAAA) & 21.17 \\
Total basic amino acids (TBAA) & 13.11 \\
Total neutral amino acids (TNAA) & 42.56 \\
\hline
\end{tabular}

\section{Conclusion}

The results obtained showed that Naja nigricollis is nutritionally rich in protein, some valuable minerals and essential amino acids but low in fat. The solubility of the protein is high, its water absorption capacity and stability, emulsion capacity and stability are favourable. Therefore, it is nutritionally good for human consumption and baby food formulations.

\section{References}

Abulude FO (2007), Determination of the chemical composition of bush meats found in Nigeria, Am. J. Food Tech. 2: 153-160

Adeyeye EI, Akinyugha NJ, Fesobi ME and Tenabe VO (1996), Determination of some metals in Clarias gariepinus, Cyprinus carpio and Oreochomis niloticus fishes in a poly culture fresh water pond and their environments, Aquaculture. 147: 205-214.

Akerele IA and Edward CC (1971), An assessment of the nutritive value of a maize-soy mixture, as a wearing food in Nigeria, Br. J. Nutri. 26: 177-185.

AOAC(2005), Official methods of Analysis 15th edition, Association of official analytical chemists, Washington D.C, U.S.A

Babalola OO and Akinsoyinu AO (2009), Proximate composition and mineral profile of snail meat from different breeds of land snail in Nigeria, Pak. J. Nutr. 8:18421844.

Beuchat LR (1977), Functional and electropheretic characterisitics of succinylated pea nut flour protein, J. Agric. Food Chem. 25: 258-261.

Coffman C and Garcia VV (1977), Functional properties of protein isolated from mung bean flour, J. Food Tech. 12: $437-484$

Guner SB, Dincer N,Alemdag A, Colak B and Fufekci M (1998), Proximate composition and selected mineral content of commercially important fish species from the black sea, J. of Food Agric. 78: 337-342.

Miller SA and Harley JP (2005), Biology of the invertebrates, 6th ed. Mc Graw - Hill, Pough.

Olaofe O, Arogundade LA, Adeyeye, EI and Falusi OM (1998), Composition and food properties of the variegatus grasshopper (Z. variegatus), Trop Sci. 38: 233 237. 
Odukoya OO and Ajayi SO (1987), Trace heavy metals in Nigeria fishes II: Copper and zinc, Nig. J. Nutr. Sci. 8: 41-49.

Ogungbenle HN and Omowole BM (2012), Chemical, functional and amino acids composition of periwinkle meat, Int. J. Pharm. Sci. Rev. \& Res. 13: 128 - 132.

Sales J and Hayes JP (1996), Proximate, amino acid and mineral composition of Ostrich meat, Food Chem. 56:167-170.

Sathe SK, Deshpande SS and Salunkhe DK (1982), Functional properties of lupin seed protein, J. Food Sci. 47: 491-497.
Simonova MP, Chrastinova L, Mojto J, Laukova A, Szabova R and Rafay P (2010), Quality of rabbit meat and phyto-additives. Czech. Food Sci. 28: 161-167.

Spackman GH, Stein EH and Moore S (1958), Automatic recording apparatus for use in the chromatography of amino acids, Anal. Chem. 30 : 1190 - 1206.

Yasumatsu K, Sawada K, Moritaka SM, Salei M, Toda J, Wada T, and Ishi K (1972), Whipping and emulsifying properties of soy bean products, Agric. Biochem. 719727.

Received: 19 February 2012; Revised: 12 June 2013; Accepted: 08 July 2013. 